\title{
Vulnerability Assessment of Forest Fringe Villages of Madhya Pradesh, India for Planning Adaptation Strategies
}

\author{
Ram Nayan Yadava ${ }^{1, *}$ and Bhaskar Sinha ${ }^{2}$ (D) \\ 1 FPM in Ecosystem and Environment Management, Indian Institute of Forest Management, \\ Bhopal 462003, India \\ 2 Chairperson, Centre for Climate Change Studies \& Faculty in Ecosystem and Environment Management, \\ Indian Institute of Forest Management, Bhopal 462003, India; bsinha@iifm.ac.in \\ * Correspondence: ramnayan75@gmail.com or rny.nayan@gmail.com; Tel.: +91-755-277516/2773799; \\ Fax: +91-755-2772878
}

Received: 12 November 2019; Accepted: 5 February 2020; Published: 10 February 2020

\begin{abstract}
This study aims to assess the climate change vulnerability of forest fringe villages of Madhya Pradesh, India, and to identify the major drivers of vulnerability, which could help to develop effective adaptation strategies. A total of 325 households spread in 29 villages of Hoshangabad, and Mandla districts were chosen for primary data collection during the summer of 2015. The selection of villages and households was carried out through stratified random sampling and systematic random sampling, respectively. The vulnerability index (score) was developed and analyzed with respect to the different socioeconomic parameters. The analysis revealed that it is not the social class of a household but the economic condition, level of education, and type of occupation/livelihood of the members of a household that are significant factors influencing the vulnerability of a household. Such findings suggest that government programs need to be designed to address the welfare of all social classes in the forest fringe villages. The study has significance in terms of providing a framework for prioritizing target households for different programs related to vulnerability reduction in the forest fringe areas.
\end{abstract}

Keywords: climate change; rural India; tribal; sustainable development; socioeconomic parameters

\section{Introduction}

Climate change is one of the most critical challenges in human history and has impacted all sectors globally in the form of a shift in seasons, increase in temperatures, and rise in sea levels. Such changes have resulted in water scarcity and reduced agricultural production, and have significantly hampered ecosystem services [1-3]. Climate change's impacts may include sudden changes linked to thresholds, especially for vulnerable, complex systems, leading to massive and widespread consequences [4]. In Asia, the significant impacts of climate change have been observed in the sectors of agriculture, water resources, terrestrial ecosystems and biodiversity, coastal zones and human health (malaria, dengue, and other vector-borne diseases) [5]. As per the IPCC, the poor and marginalized sections of the society are more vulnerable to such impacts, especially the rural poor from developing countries, because of their higher exposure to extreme climatic events, high level of dependence on natural resources, widespread poverty, marginalization, and fewer adaptation options [3,6]. Moreover, climate change and climate variability are threatening the delivery of a range of crucial goods and environmental services from forests, on which an estimated 1.6 billion people fully or partly depend globally [7]. Thus, climate change's impacts on forests will hit the forest-dependent community hardest, making them 
even more vulnerable. Therefore, climate change vulnerability assessment of forest-dependent people is important to design suitable adaptation strategies [8,9].

Globally, studies have attempted to establish a link between climate change and poverty, framing it in terms of vulnerabilities, accounting for one's exposure, and the capacity to adapt to climate risk [2]. The vulnerability due to climate change has three deterministic components, exposure, sensitivity, and adaptive capacity [10]. Exposure cannot be altered much at the household level as it is a climatic variation; however, the adaptive capacity and sensitivity of people can be improved to help them cope with the climatic vulnerability and reduce the impact of exposure [11]. Moreover, the data on climate variables are at the macro level; study at the micro-level has used adaptive capacity alone to assess the vulnerability $[12,13]$. Adaptive capacity refers to relatively longer-term or more sustainable adjustments that can modify a system's sensitivity and exposure to a disturbance [14]. The socioeconomic status of the household influences the capacity to cope with climate change vulnerability $[15,16]$. However, the IPCC Fifth Assessment Report has given more emphasis to mapping and managing the risks of climate change impacts resulting from the interaction of vulnerability, exposure, and hazards, whereas the previous report emphasized managing vulnerability based on measuring exposure, sensitivity, and adaptive capacity $[2,3]$.

In India, around two-thirds of the population live in rural areas and are predominantly dependent on climate-sensitive sectors, especially agriculture and forestry [17]. The projected mean annual temperature of India has increased by $0.51{ }^{\circ} \mathrm{C}$ per 100 years (1901-2007) and $0.2{ }^{\circ} \mathrm{C}$ per decade (1971-2007), with a more pronounced increase in minimum temperature as compared to the maximum temperature [18]. Additionally, the frequency of hot days shows a gradually increasing trend, and the frequency of cold days shows a significant decreasing trend during the pre-monsoon season in 1970-2005, which would further impact the agriculture and forestry sectors, making farmers and forest-dependent communities more vulnerable [19].

Furthermore, the relative level of vulnerability in India differs between states, geographical locations, and social groups within the same region. The differences in vulnerability are attributable to substantial variations in orography, climate conditions, and ecosystems, as well as differences in the social structures, economic status, and requirements of different communities. Various adaptation actions have been implemented to strengthen the adaptive capacity of vulnerable communities [13]. Moreover, the communities living in villages (approx. 1.73 lakh) situated in and around the forests (referred as "forest fringe village") in India are more vulnerable as they have a greater dependence on forest and agriculture and represent the country's poorest people [20,21]. The estimated livelihood dependence of these communities on forest varies from $37 \%$ to $76 \%$ [22]. As a result, the livelihood of indigenous communities residing in the forest is inseparable from the forests, following their use of forest ecosystem goods and services. Climate change is likely to impact Indian forests [23], which in turn will affect the livelihoods of the forest fringe villages. Moreover, the ability of these forest fringe poor to enhance their coping ability is constrained by a range of related structural, social, economic, and institutional barriers, which entails the need to assess the vulnerability and identify the drivers of vulnerability of these communities to design suitable adaptation strategies [13].

In this regard, the current study intended to understand the impact of climate change by evaluating the vulnerability of forest fringe communities in the Hoshangabad and Mandla districts of Madhya Pradesh. The state has the highest forest cover and the most forest villages, along with a sizeable tribal population, and is a known pocket of poverty [24]. Furthermore, the state experienced a significant decline in monsoon-season precipitation during 1951-2013 and also observed an increased intensity and frequency of droughts [25]. Specifically, a decline in precipitation and rainy days, along with an increase in temperature, was reported from Mandla [26], and an increase in temperature was observed in Hoshangabad [27] over the past 45 years. The impact of changing climate variables will not only affect the agricultural output and food security but will also escalate competition for natural resources, which may trigger outbreaks of vector-borne diseases. The indicator-based vulnerability 
assessment will help to identify the specific drivers/ causal factors, which in turn, would be helpful for planners/policymakers in formulating effective adaptation strategies for the forest fringe villages.

\section{Methodology}

The current study attempted to develop a composite index to assess climate change vulnerability at the household level in the forest fringe areas of Madhya Pradesh, India. This study is important for prioritizing households and identifying specific interventions, which, in turn, could help with designing adaptation strategies for forest fringe areas. Since vulnerability is a dynamic component, all the indicators related to vulnerability were chosen based on the availability of data, personal judgment, and previous research.

\subsection{Study Area}

Madhya Pradesh has a diverse social composition, a predominantly agrarian economy, a difficult and inaccessible undulating terrain along with scattered settlements over the vast area, which is mostly cutoff from mainstream development, and a low human development index (0.3753) [28]. The state is dominated by tribal populations $(20.27 \%)$, who reside in rural and forest fringe areas. Approximately half of the rural community of the state is living below the poverty line [29]. Moreover, the climate of the state is projected to change significantly, which will undermine the existing efforts related to vulnerability reduction. Mishra and Singh [30] have indicated that droughts in Madhya Pradesh have a far-reaching impact on the livelihoods of the rural poor. The problems of drought, poverty, and degradation of forest resources will be further exacerbated due to climate change, threatening the livelihoods of communities of the forest fringe villages. It is, therefore, important to map the vulnerability and identify its drivers to design suitable adaptation strategies.

\subsection{Selection of Study Site}

The state of Madhya Pradesh was selected for this study because of the presence of the maximum number of forest villages (a proxy for forest fringe villages) in the country [24,31]. In Madhya Pradesh, two districts, Hoshangabad and Mandla, were selected based on the number of forest villages and Madhya Pradesh Government composite vulnerability ranking of the districts prepared from secondary data. Hoshangabad District is less vulnerable as it is close to industrial areas and the state capital, whereas Mandla represents the most vulnerable districts of the state because of its remoteness and poor socioeconomic conditions [12]. Both districts are rich in forest resources; Hoshangabad has $36.14 \%$ and Mandla has $48.79 \%$ of its area under forest cover [20]. Furthermore, the villages selected for the study are located in the forest areas and represent the country's poorest villages [21]. A total of 325 households spread across 29 villages from both districts were chosen. The villages were selected using stratified random sampling. The wealth ranking of households in each selected village was carried out through a participatory rural appraisal (PRA) to stratify households. The households in the villages of each stratum were selected by using systematic random sampling for primary data collection (Figure 1). The selection of respondents was not less than $5 \%$ in each stratum. 


\section{Location of the Study Area and Vulnerability Scores of the two Districts}

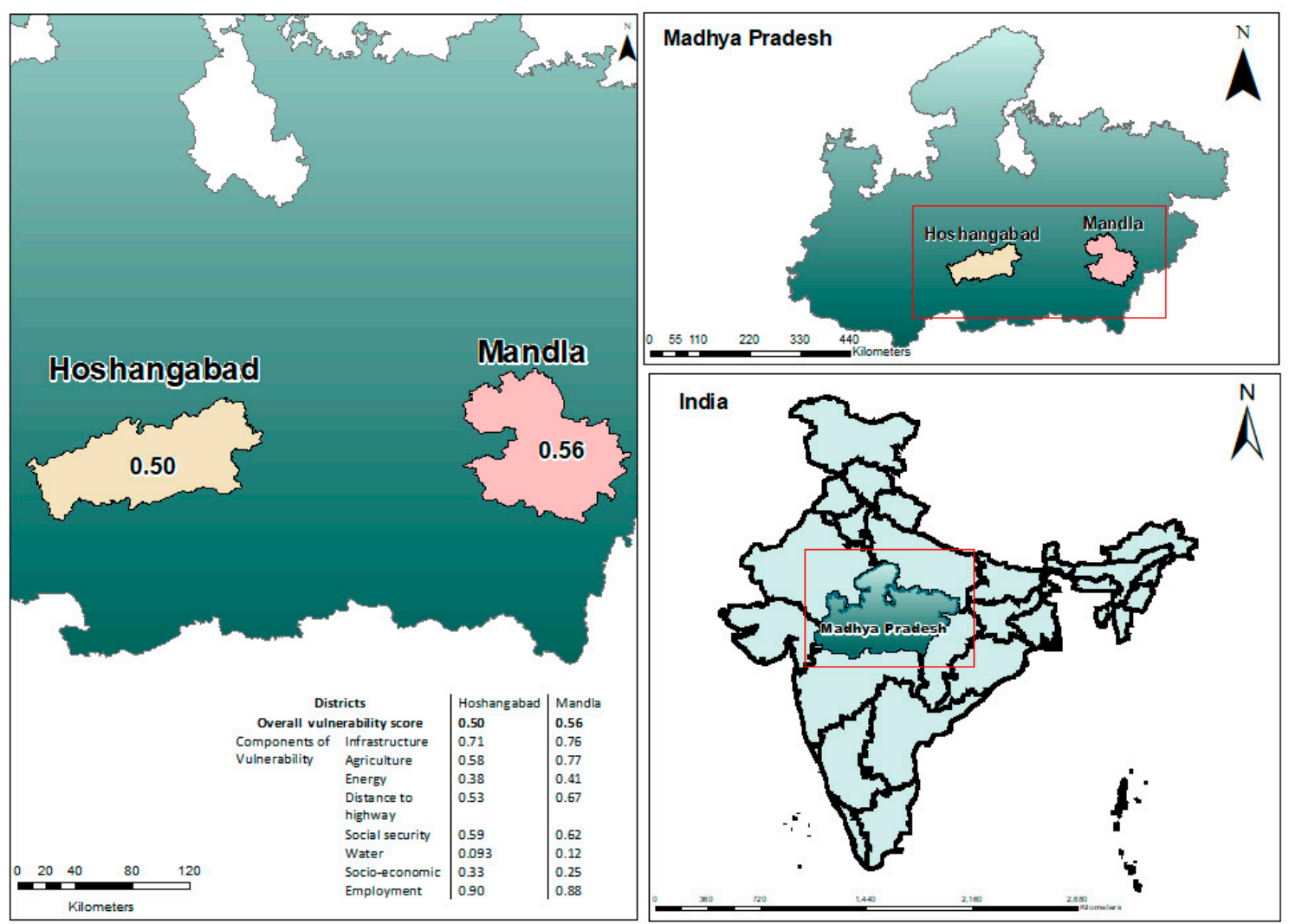

Figure 1. Spatial representation of study site and vulnerability score.

\subsection{Identification and Selection of Indicators}

Indicators constitute readily available information that can be obtained easily in a pragmatic manner. The indicator has been defined as a variable and measure of system behavior in terms of meaningful and perceptible attributes [32]. A variable is an operational representation of an attribute (quality, characteristic, property) of a system and, generally, a variable indicates an attribute [14]. There is no universally accepted list of indicators that characterize either vulnerability or a standardized method of combining them to form a vulnerability index. Climate vulnerability assessment carried out using a composite index provides comparative results rather than absolute values, which range between 0 (least vulnerable) and 1 (most vulnerable) [33]. Based on the review of the literature and a reconnaissance survey, dimensions and indicators of household vulnerability were chosen. These indicators were considered to be comprehensive and relevant in the rural context. In addition to the review of the literature, the list of indicators was further updated through PRA to capture the various dimensions and indicators of vulnerability in the forest fringe villages (Appendix A). This is a systematic process of assigning a value to each indicator, such as agricultural land, irrigation, and type of house, in a numerical form, considering the previous approach of the Human Development Index (HDI) and LVI by [34] and [35]. To identify the significant indicator, [36] used Principal Component Analysis (PCA) for extraction, and the Varimax method for the rotation of the factors in Statistical Package for Social Science (SPSSv.20). The result of communalities (extraction) indicates that, for all the indicators, a high amount of variance could be explained by the factor analysis model (Table 1). Mohanty et al [37] used a communality value of more than 0.6 as a sufficient condition to keep the indicators in the factor analysis model. In this respect, PCA was performed to find the significant indicators having more than 0.6 communalities. It was found that five indicators had lower communalities, which were removed from the list, and PCA was conducted again for further removal. However, all these indicators showed communalities of more than 0.6 and were accepted (Table 1). 
Table 1. Factors and indicators of vulnerability derived after principal component analysis.

\begin{tabular}{|c|c|c|c|}
\hline $\begin{array}{c}\text { Factors } \\
\text { (\% of Variance) }\end{array}$ & Weight & Indicators & Extraction \\
\hline \multirow{8}{*}{$\begin{array}{l}\text { Income and Assets } \\
\qquad(15.55 \%)\end{array}$} & \multirow[t]{8}{*}{20.8} & Total numbers of livestock & 0.682 \\
\hline & & Type of house & 0.706 \\
\hline & & Presence of a toilet & 0.656 \\
\hline & & Total family income & 0.732 \\
\hline & & Daily water use (liters) & 0.709 \\
\hline & & Source of cooking fuel & 0.750 \\
\hline & & Number of appliances for lighting & 0.859 \\
\hline & & Number of appliances for heating and cooling & 0.730 \\
\hline \multirow{6}{*}{ Agriculture (13.34\%) } & \multirow[t]{6}{*}{17.8} & Total landholding & 0.744 \\
\hline & & Total irrigated land & 0.801 \\
\hline & & Number of crops & 0.704 \\
\hline & & Source of irrigation & 0.772 \\
\hline & & Instruments for plowing and sowing & 0.776 \\
\hline & & Instruments for threshing & 0.827 \\
\hline \multirow{2}{*}{ Market access (6.71\%) } & \multirow[t]{2}{*}{9.0} & Total earning members & 0.602 \\
\hline & & Distance to highway & 0.674 \\
\hline \multirow{2}{*}{ Social capital $(6.69 \%)$} & \multirow{2}{*}{9.0} & Participation in panchayat & 0.851 \\
\hline & & Member of SHGs & 0.869 \\
\hline \multirow{3}{*}{ Energy $(6.3 \%)$} & \multirow{3}{*}{8.4} & Source of lighting & 0.681 \\
\hline & & Total spending on energy & 0.715 \\
\hline & & Consumption of fuelwood (per day) & 0.823 \\
\hline \multirow{2}{*}{ Water access $(6.03 \%)$} & \multirow{2}{*}{8.1} & Distance to drinking water & 0.874 \\
\hline & & Time spent on water collection & 0.891 \\
\hline \multirow{2}{*}{ Family size (5.88\%) } & \multirow{2}{*}{7.9} & Total family members & 0.895 \\
\hline & & Total number of children & 0.852 \\
\hline \multirow{2}{*}{ Health facilities (5.4\%) } & \multirow{2}{*}{7.2} & Access to medical facility in village & 0.714 \\
\hline & & Proximity to multispecialty hospital & 0.712 \\
\hline Permanent job (4.68\%) & 6.3 & Permanent job & 0.680 \\
\hline \multirow{3}{*}{ Awareness (4.16\%) } & \multirow{3}{*}{5.6} & Highest family education & 0.605 \\
\hline & & Farmer loan facility(KCC) & 0.747 \\
\hline & & Quality of water & 0.650 \\
\hline
\end{tabular}

\subsection{Normalization of Indicators}

A total of 31 relevant indicators were identified from the PCA and were used to assess vulnerability. The different indicators have different units and scales; therefore, the normalization of indicators for scales and units was done by utilizing the methodology of the Human Development Index (HDI) based on their functional relationship between the indicators and vulnerability. There are two types of functional relationship, positive or negative. In a positive relationship (Equation (1)), the value of vulnerability increases with an increase in the value of the indicator, whereas in a negative relationship (Equation (2)), the value of vulnerability increases with a decrease in the value of indicators [34,38].

$$
\begin{aligned}
& \operatorname{Index}\left(s_{v}\right)=\frac{s_{v}-s_{\text {min }}}{s_{\text {max }}-s_{\text {min }}} \\
& \operatorname{Index}\left(s_{v}\right)=\frac{s_{\text {max }}-s_{v}}{s_{\text {max }}-s_{\text {min }}}
\end{aligned}
$$

where $S_{v}$ is the average value of the indicator at the respondent level. $S_{\min }$ and $S_{\max }$ are the minimum and maximum values, respectively, of the indicator at the respondent level. 
After the normalization of each indicator, the values were averaged using Equation (3) to calculate the value of each index.

$$
M_{v}=\frac{\sum_{i-1}^{n} \text { Index }}{n}
$$

where $M_{v}$ is the index of one of the components, An index is the indicator value of the Ith indicator, and $n$ is the number of cases/indicators in the index.

A detailed household survey was conducted to assess climate vulnerability using the above indicator for the sampled household.

\subsection{Weight Assignment}

There is a need to assess vulnerability based on statistics and not researcher judgment. Moreover, theoretical weighting and analysis approaches are difficult to construct, particularly for a large number of indicators [39]. Therefore, the statistical method is an unbiased way to assign the weight to each indicator/factor. The previous approach of assigning a uniform weight to all factors, as reported by Pandey and Jha [40], may not be applicable in this region because of the high variability among indicators in influencing the vulnerability/adaptive capacity. Esteves et al [36] also reported a statistical approach for assigning the weight in the same region. PCA was used to group the indicators and assign weights. PCA helps to generate weights, based on the assumption that there are common factors that explain the variance. PCA (Varimax rotation) was performed on all selected indicators. The factors with eigenvalues greater than one were included in the analysis. The rotated factor analysis generated 10factors from 31 indicators, with eigenvalues greater than 1, which accounted for approximately $75 \%$ of the total cumulative variance in the dataset compiled for the assessment of vulnerability (Table 2).

As per the methodology, the process of assigning weights to selected indicators was done by the significance of their contribution to vulnerability. Weights for the 10factors were calculated using the formula $\mathrm{E}(1$ or 2 or $\ldots \mathrm{10}) / \mathrm{E} 1+\mathrm{E} 2+\ldots \mathrm{E} 10$, where $\mathrm{E} 1$ is the eigenvalue for the 1st factor (value $>1$ ); E2 is the eigenvalue for the 2nd factor (value $>1$ ); E10 is the eigenvalue for the 10thfactor (value $>1$ ). The calculation of weight using the Eigenvalue was based on a general formula of the weight for factor-1 $(\mathrm{W} 1)=\mathrm{E} 1 /(\mathrm{E} 1+\mathrm{E} 2+\ldots \mathrm{E} 10)$, and the same was also applied for other factors. For example, factors 1,2,3,4,5,6,7,8,9,10 have eigenvalues of 4.822, 4.137, 2.08, 2.077, 1.956, 1.869, 1.823, $1.677,1.451$, and 1.292 , respectively, and the weight for factor 1 was calculated by using this formula $(4.822 /(4.822+4.137+2.08+2.077+1.956+1.869+1.823+1.677+1.451+1.292))$. The value for the total sample, i.e., vulnerability index, was calculated using the formula $(\mathrm{W} 1 *$ factor- 1$)+(\mathrm{W} 2$ * factor- 2$)$ $+\ldots(\mathrm{W} 10 *$ factor-10), where W1, W2 ...W10 are the weights calculated for respective factors to generate a unit less value for each factor by running PCA (Tables 1 and 2). The weighted value of each factor was added up to get the composite index of vulnerability.

Table 2. Result of principal component analysis for eigenvalue greater than 1.

\begin{tabular}{|c|c|c|c|c|c|c|c|c|c|}
\hline \multirow{2}{*}{ Component } & \multicolumn{3}{|c|}{ Initial Eigenvalues } & \multicolumn{3}{|c|}{$\begin{array}{l}\text { Extraction Sums of } \\
\text { Squared Loadings }\end{array}$} & \multicolumn{3}{|c|}{$\begin{array}{l}\text { Rotation Sums of } \\
\text { Squared Loadings }\end{array}$} \\
\hline & Total & $\begin{array}{c}\% \text { of } \\
\text { Variance }\end{array}$ & Cumulative\% & Total & $\begin{array}{c}\% \text { of } \\
\text { Variance }\end{array}$ & Cumulative\% & Total & $\begin{array}{c}\% \text { of } \\
\text { Variance }\end{array}$ & Cumulative $\%$ \\
\hline 1 & 8.54 & 27.56 & 27.56 & 8.54 & 27.56 & 27.56 & 4.82 & 15.55 & 15.55 \\
\hline 2 & 2.57 & 8.31 & 35.88 & 2.57 & 8.31 & 35.88 & 4.13 & 13.34 & 28.90 \\
\hline 3 & 2.16 & 6.99 & 42.87 & 2.16 & 6.99 & 42.87 & 2.08 & 6.71 & 35.61 \\
\hline 4 & 2.05 & 6.61 & 49.48 & 2.05 & 6.61 & 49.48 & 2.07 & 6.69 & 42.30 \\
\hline 5 & 1.94 & 6.27 & 55.76 & 1.94 & 6.27 & 55.76 & 1.95 & 6.30 & 48.61 \\
\hline 6 & 1.45 & 4.70 & 60.46 & 1.45 & 4.70 & 60.46 & 1.86 & 6.02 & 54.64 \\
\hline 7 & 1.21 & 3.92 & 64.38 & 1.21 & 3.92 & 64.38 & 1.82 & 5.88 & 60.52 \\
\hline 8 & 1.11 & 3.58 & 67.97 & 1.11 & 3.58 & 67.97 & 1.67 & 5.40 & 65.93 \\
\hline 9 & 1.06 & 3.43 & 71.41 & 1.06 & 3.43 & 71.41 & 1.45 & 4.68 & 70.61 \\
\hline 10 & 1.04 & 3.37 & 74.78 & 1.04 & 3.37 & 74.78 & 1.29 & 4.17 & 74.78 \\
\hline \multicolumn{10}{|c|}{ Extraction Method: Principal Component Analysis. } \\
\hline
\end{tabular}




\section{Results and Discussion}

The overall vulnerability score and component of vulnerability computed for both study districts indicate that Mandla is more vulnerable than Hoshangabad (Figure 1). The analysis also included understanding the influence of different socioeconomic parameters (social class, economic class, level of education, and livelihood options) on the vulnerability of a household.

\subsection{The Vulnerability of Different Social Classes}

The social structure of India is grouped into four classes, General (Forward caste), Other Backwards Caste (OBCs), Schedule Caste (SC), and Schedule Tribe (ST).In the case of forest fringe villages, ST, $\mathrm{SC}$, and $\mathrm{OBC}$ are the prominent social groups. Based on the composite vulnerability index of the total sampled population, SC scored the minimum vulnerability score, followed by OBC and ST, to cope with the adverse impacts of climate change (Table 3). The posthoc LSD of ANOVA revealed that the scores of different social groups of Mandla district are not significantly different, which implies that the socioeconomic conditions are more or less similar, as also observed during the fieldwork. However, a significant difference was observed between OBCs and ST communities in the Hoshangabad district and the total sampled households of both districts (Appendix B). Such a distinct difference in Hoshangabad maybe because of its proximity to industrial areas and the state capital, where some of the OBCs are employed. However, Mandla is a remotely located district and has poor employment opportunities, leading to poor economic status for all the communities. A similar observation was also made by Ganesan and Vishnu [41]: the disparity between the social groups is linked to the underlying differences in economic status between the various groups in rural India. Another study by Goli et al [42] in Uttar Pradesh concluded that there exists a huge inequality regarding critical socioeconomic indicators, despite six decades of welfare policies and schemes to improve the social class system. However, in the case of forest fringe villages, the disparity amongst the social groups is not that significant. Therefore, the government programs need to be designed in such a way that they address the welfare of all social classes.

Table 3. Vulnerability score of households based on social, economic, education, and occupation types.

\begin{tabular}{cccc}
\hline Social Class & Total Sample & Hoshangabad & Mandla \\
\hline ST & 52.06 & 50.17 & 54.59 \\
SC & 49.19 & 48.08 & 58.77 \\
OBCs & 51.61 & 45.42 & 55.98 \\
\hline Economic Class & Total Sample & Hoshangabad & Mandla \\
\hline AY & 54.17 & 55.07 & 53.67 \\
BPL & 52.02 & 48.81 & 57.7 \\
APL & 43.44 & 44.26 & 40.14 \\
\hline Level of Education & Total Sample & Hoshangabad & Mandla \\
\hline Illiterate & 54.92 & 53.72 & 56.77 \\
Middle (8th) & 52.99 & 49.95 & 56.02 \\
Matric (10th) & 49.59 & 46.73 & 54.92 \\
Secondary or intermediate (12th) & 53.26 & 44.87 & 42.27 \\
Graduation & 42.41 & 42.27 & Mandla \\
Occupation & Total Sample & Hoshangabad & \\
(Livelihood Option) & & & 56.38 \\
Labor class & 53.84 & 51.89 & 44.78 \\
Other class & 47.05 & 41.12 & \\
Salaried class & 40.85 & 39.28 & \\
\hline
\end{tabular}




\subsection{The Vulnerability of Different Economic Classes}

The government of India, based on certain criteria of economic deprivation, has categorized households into three different categories, namely Antyodaya (AY), Below Poverty Line (BPL), and Above Poverty Line (APL). The households belonging to the bottom of the economic class are AY, and have the highest vulnerability (high score). APL households have lower vulnerability than BPL and AY households. Drill-down analysis of vulnerability found a similar result for both districts as well as in total sample (Table 3). The posthoc LSD of ANOVA reveals that the economic condition of a household has a significant role in the vulnerability of a household in all the conditions (Appendix B). The beneficiaries of some of the existing programs implemented by the government and non-government agencies are prioritized based on this economic classification (AY, BPL and APL), and this should continue. However, during participatory rural appraisal (PRA), some of the villagers reported that the economic categorization of households (APL/BPL/AY) needs to be reviewed. Moreover, there should be programs for capacity building of economically deprived (AY/BPL) families in rural India so that they can avail themselves of the benefits of ongoing government programs, as also emphasized by Swaminathan [43].

\subsection{The Vulnerability of Different Education Levels}

Education is one of the critical factors determining the adaptive capacity of vulnerability [39]. As the education level increases, the capacity to adapt to climate change vulnerability also increases, which was also observed in our study at the district level (Table 3). The post-hoc LSD of ANOVA showed that education was a significant factor influencing the vulnerability of a household in Hoshangabad district and the total sample, except between matric (10th standard) and intermediate (12th Standard). However, the impact of education on vulnerability score was not significant in the case of Mandla (Appendix B). Such contrasting results show that education is an important factor for reducing vulnerability in those villages that have access to the market and job opportunities, as was the case in Hoshangabad district. However, for households/villages that are remotely situated (Mandla), education was not influential on vulnerability. The integration of education and skill development programs of the government (PMKVY) and corporations (corporate social responsibility (CSR)) may help with improving the employment and economic situation, which, in turn, would help with reducing the household's vulnerability [44], especially in the context of forest fringe villages.

\subsection{The Vulnerability of Different Type of Livelihoods}

The type of livelihood is the most important factor that influences rural households' socioeconomic condition. The five types of capital, namely human, financial, social, physical, and natural, are influenced by the types of livelihood that the communities are associated with [45]. In the sampled households, most of the households were composed of day-wage laborers with poor education and economic conditions. As we move from daily wage labor to other classes (household members also involved in small businesses or shops, as hawkers or vegetable sellers, etc.) and then to the salaried class (at least one of the family members has a permanent job), the vulnerability score showed a decreasing trend. The drill-down analysis also showed a similar result for both the districts and for the total sample as well (Table 3). A significant difference in the vulnerability score was recorded between households with different livelihood options, except between the households belonging to the 'other' class and salaried class in Hoshangabad (Appendix B). Households belonging to the 'other' class in Hoshangabad district have more opportunities in terms of setting up small enterprises or the possibility of employment due to proximity and linkages to industrialized cities, like Itarsi, Hoshangabad, and Mandideep. The findings of this study are similar to those of Hahn et al [35], who reported that a household's livelihood options determine its vulnerability to climate change. Jha et al [13], too, observed that the change in livelihood options impacted vulnerability in the same region. Therefore, 
rural development programs aimed at enhancing the livelihood of households should be promoted in forest fringe villages for vulnerability reduction, as also recommended in other similar studies $[13,44]$.

\subsection{Socioeconomic Characteristics of the Different Vulnerable Groups}

The vulnerability score, which ranged from 28 to 69 on a scale of 0 to 100,was grouped into three groups, low, moderate, and high, with the help of software (SPSS) using a binning technique based on an equal width interval with the idea of understanding the socioeconomic status of households in more detail $[46,47]$.The scores for the least vulnerable group ranged from 28 to 47 ; the moderately vulnerable group scored from 48 to 57 ; and the scores of the highly vulnerable group ranged from 58 to 69. As we moved from less to more vulnerable groups, the socioeconomic characteristics changed accordingly. In terms of economic class, the vulnerability decreases as we move from AY to BPL and from BPL to APL. However, among the social groups, differences between communities were observed only in Hoshangabad, not in the Mandla district. With respect to the households with different livelihood options, households with labor as the major occupation had the maximum vulnerability and households with a salaried member had the minimum vulnerability. Similarly, vulnerability showed a declining trend with an increase in the education level. Furthermore, no households with higher education (graduation and above) were found in the highly vulnerable group (Figure 2). The analysis clearly indicates that AY households without any formal education and engaged in daily wage earning are the most vulnerable population in the forest fringe villages. This also implies that these households should be given top priority to receive the benefits flowing from different government programs or CSR related to adaptation and development. There should be innovative programs to improve their education and skills, which, in turn, will enable these communities to diversify their livelihood options and enhance their income, ultimately improving their adaptive capacities.

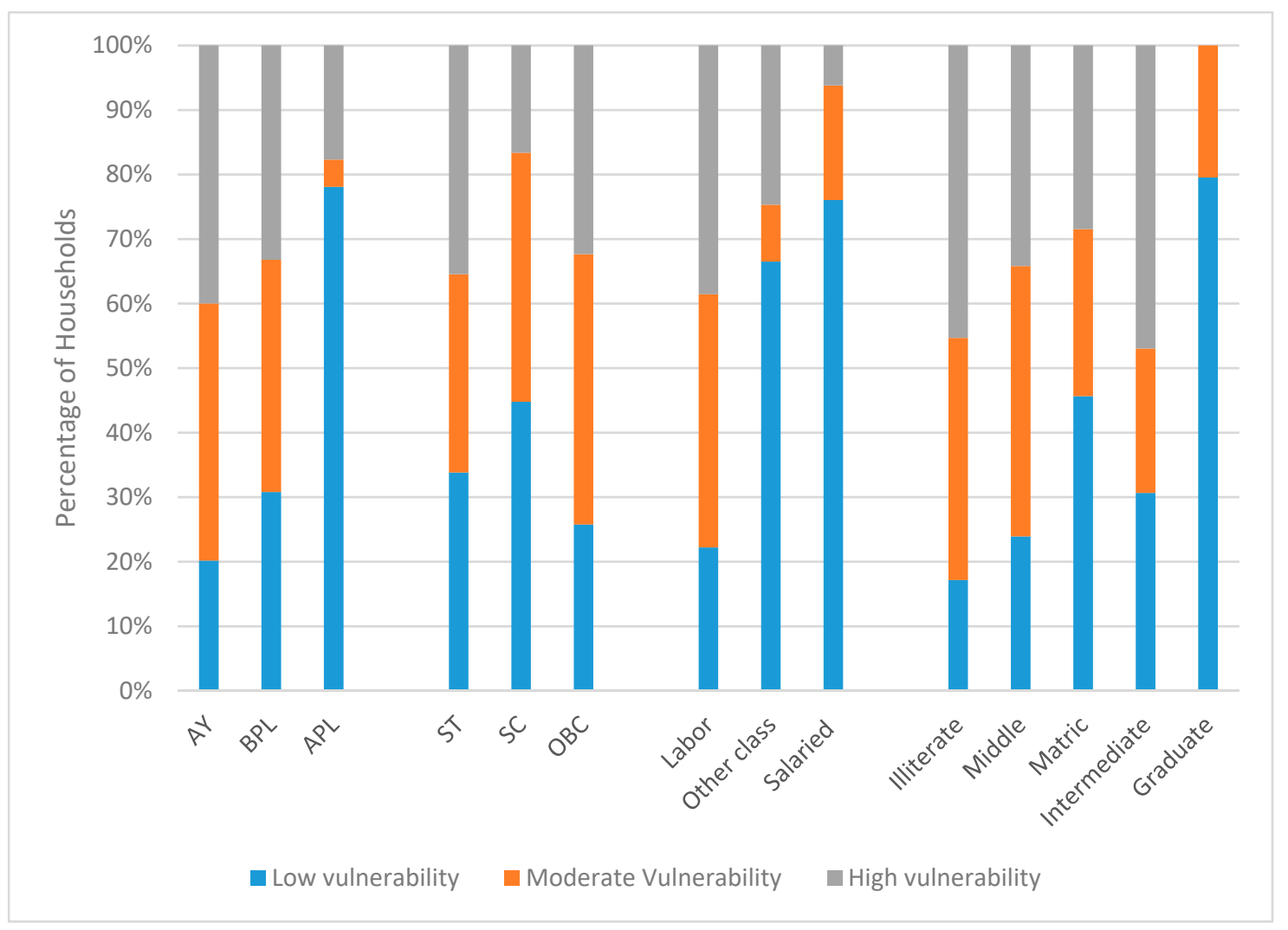

Figure 2. Percentage of house holds in different class of vulnerability based on different socioeconomic parameters. 


\subsection{Factor-Wise Analysis of Vulnerability}

The study identified 31 indicators to measure the vulnerability to climate change of the forest fringe villages in the state of Madhya Pradesh of India, which were further grouped into 10factors through PCA. These are: Income and assets, Agriculture, Access to the market, Social capital, Energy, Water, Family size, Health, Livelihood options and awareness (Table 1).

\subsubsection{Income and Assets}

This factor (income and assets) is comprised eight indicators (the type of house and cooking fuel, number of livestock, presence of toilet, total income, and presence of appliances used for lighting, cooling, and heating) and accounts for $15.55 \%$ of vulnerability in the study area, which highlights the need for promoting income-generating activities and building assets (Table 1). Different government programs, like Indira Awas for house construction, the Ujwala scheme for modern cooking fuel, and MGNREGA for guaranteed employment, should be implemented and monitored effectively to improve the income and assets that, in turn, will increase their adaptive capacities to cope with climate change [13]. Moreover, CSR programs should be used to create assets and income sources in rural areas to reduce vulnerability.

\subsubsection{Agriculture}

India being an agrarian economy, most of its population is dependent on agriculture (70\%) as per the Census of India [17]. In this study, the agriculture factor consisted of total land, percentage of irrigated land, diversity of crops, sources of irrigation, and instruments used for plowing, sowing, and threshing, and contributed $13.34 \%$ of the total vulnerability in the sampled households (Table 1 ). Sustainable agriculture is one of the goals in the national action plan on climate change of the Indian government. While studying the role of CSR in agriculture and the socioeconomic conditions of farmers in Hoshangabad district, Yadava and Sinha [44] also reported that CSR, along with government programs, has the ability to enhance agricultural productivity. Furthermore, sustainable supply chain management must be ensured to get fair prices for agriculture products that could further enable small farmers to cope with vulnerability.

\subsubsection{Access to the Market}

Access to the market and roads is an important factor in mainstreaming development for any remote area. This factor consists of the total number of wage-earning members in a household, and distance to the highway. The factors contribute $6.71 \%$ of the vulnerability. Linkage with roads leads to linkage with the market and subsequently provides more job opportunities. Government programs like Mahatma Gandhi National Rural Employment Guarantee Act, the Prime Minister Village Road Scheme, and other related programs have immense potential for developing the rural infrastructure and improving access to the market through the construction of roads [48]. Improved access to the market enables them to get more employment and increase their earnings, which reduces vulnerability by enhancing their adaptive capacity, aswas also observed by Pandey et al [49].

\subsubsection{Social Capital}

Social capital refers to meaningful bonds between communities that help in an adverse situation. Although social bonding in the fringe areas is better than in other rural and urban areas, it is slowly diminishing nowadays, as observed during the field visit. This factor contributed $6.69 \%$ of total vulnerability. Participation in the Panchayati Raj institutions (government-elected bodies for the lowest level of governance) and being a member of a self-help group (SHGs) are the two significant indicators used to measure social capital. The active role of Panchayati raj institutions of the government can help households to get benefits from a number of schemes implemented by the government. Similarly, SHGs help people to get assistance from group members as well as banks and other microfinance institutions. 
These two variables are considered an important way to bring about economic transformation in rural India [50]. Financial assistance from communities/relatives could be one of the best ways to get support instantly without a mortgage or legal supporting documents; this support could be utilized by an individual at any time of scarcity to help them survive, aswas also reported by Jha et al [13].

\subsubsection{Energy}

Although energy contributes only $6.3 \%$ to total vulnerability, its contribution to agriculture and other income-generating activities has not been covered here. A number of recommendations for implementing renewable energy technology in these forest villages can be adopted from the study done by Sinha et al [24], which is relevant to this study as well. Access to energy not only improves their working hours but also helps in transforming the livelihood of households from primary to secondary and tertiary, which ultimately leads to an enhanced coping capacity of households when faced with environmental extremes [12].

\subsubsection{Water Access}

This factor consists of distance to drinking water sources and time spent on water collection. It contributes $6.03 \%$ of the total vulnerability, despite both districts happening to be part of the catchment area of the Narmada River, an important perennial river of the region. Except for the households close to Narmada River, the remaining region is drought-prone with rocky land, which further limits access to water for drinking as well as irrigation [24,33]. This means that, with the use of proper infrastructure and support, the water accessibility in this region can be significantly improved. A government program called "Jal Dhara" is helping people to gain improved access to water in many areas. Additionally, this will minimize the problems involved with women fetching water from a distant place (sexual abuse, lack of education, and limited ability to make a livelihood), leading to an enhanced capacity to cope with climate vulnerability.

\subsubsection{Family Size}

The size of a household is an important component in determining the vulnerability; this factor is composed of the total number of family members including children. Family welfare schemes, and especially family planning, may be effectively implemented to control the population and reduce overall vulnerability. The total contribution of family size to vulnerability was $5.88 \%$. A smaller family size or fewer dependent family members led to an improved adaptive capacity.

\subsubsection{Health Facilities}

Health problems like malaria and encephalitis are frequently reported in these areas, with further increases likely due to climate change and contaminated water. Massive awareness campaigns, along with a primary healthcare center in the villages and a hospital in the nearby city, could help the communities to cope with risk, contributing to $5.4 \%$ of the overall vulnerability. Access to health facilities will help households to minimize health-related problems, including those due to vector-borne diseases that will increase thanks to climate change [4].

\subsubsection{Permanent Jobs}

From the analysis and field survey, it was evident that households having at least one family member with a permanent job were the least vulnerable. Good education, along with new skills, may help them to find a job and reduce their vulnerability. A recent program like the Prime Minister's Skill Development Scheme (PMSDS) could help these forest fringe people. The contribution of the permanent job was only $4.68 \%$ in overall vulnerability. However, a permanent job provides a regular and secure source of income, leading to reduced vulnerability. 


\subsubsection{Awareness}

Education played an important role in increasing awareness in society and contributed $4.16 \%$ of total vulnerability. Apart from education, participation in social functions and exposure to the market make people more aware. This factor consisted of education, access to government credit schemes (in the form of $\mathrm{KCC}$ ), and potable water. It was interesting to note that the majority of people using KCC were educated, whereas other people were skeptical about this facility, as observed during the field survey. A similar observation was also reported by Sinha et al [24] in a similar study in the state. Climate change induced by anthropogenic activities has created a number of problems, which not only require sociotechnical solutions but also enhanced awareness to get better results in terms of reducing vulnerability [3].

\subsection{Prioritization of Programs and Policies Based on Vulnerability Mapping}

The regression between the score of climate change vulnerability index as a dependent variable and social class, economic class, level of education, and type of livelihood (occupation) as independent variables showed a significant order of influence, which may suggest an order for the prioritization of programs and policies. As per the standard coefficient (beta), the variables were, the type of occupation, level of education, economic class, and social class (Appendix C). Such findings suggest that programs and policies targeted to reduce vulnerability in these areas could prioritize the households/villages based on the type of occupation, followed by the level of education and economic class. However, social class is the least influencing variable, which implied that the programs and policies should not be based on social class, which was in contrast to other findings from India [51]. Such insight reiterates that policies/programs/schemes/aids aimed at minimizing vulnerability in the forest fringe villages should not be based on social groups.

\section{Conclusions}

This study revealed that the economic background (AY/BPL/APL), education (level of education), and occupation of a household are the significant factors determining the level of vulnerability. Furthermore, the households under three vulnerability classes (low, moderate, and high) show that the percentage of ST households who were illiterate laborers belonging to the AY class was highest in the most vulnerable group. Such findings suggest that it is not the social class but the economic, education, and occupation status of a household that are appropriate indicators to use when prioritizing households for programs and policies related to climate change vulnerability reduction by the government or any other implementing agencies in these regions. Careful preparation and regular updating of the database with respect to the householders' economic status (AY, BPL and APL) and education level, especially in these remote villages, may help to improve the outcomes of government programs.

The analysis of the impact of different indicators on vulnerability using PCA also emphasized a need for enhancing income, creating assets, strengthening agricultural practices, and developing market linkages while designing adaptation programs. The impact of education was a significant factor in the vulnerability reduction of Hoshangabad (a district with proximity to the market/industry) but not of Mandla (a district with poor access to the market), which implied that education alone might not bring about the desired results. The integration of education and skill development programs by the government and corporations (CSR) may help with employment and the economy, especially in the context of forest fringe villages. The study has significance in terms of providing a framework by which to prioritize target households for different programs related to vulnerability reduction in the forest fringe areas.

Author Contributions: R.N.Y. has contributed in research design, field and data collection, analysis, interpretation, drafting and writing of article. B.S. has supervised over all research and helped in designing, writing and refining the article. All authors have read and agreed to the published version of the manuscript.

Funding: The research received no external funding.

Conflicts of Interest: There is no conflict of interest of any kind. 


\section{Appendix A}

Table A1. Vulnerability Indicator Selection, with Data Collected at the Household Level.

\begin{tabular}{|c|c|c|}
\hline Component of Vulnerability & Indicator/Index & Explanation of Indicator \\
\hline \multirow[t]{5}{*}{ Agriculture } & Total land & Acts as an asset \\
\hline & Total irrigated land & Good for crop production \\
\hline & Number of crops & Agriculture diversity and cash crops \\
\hline & Instrument for plowing and sowing & $\begin{array}{l}\text { Mechanization of agriculture } \\
\text { (Minimum human labor) }\end{array}$ \\
\hline & Instruments for threshing & Low human effort and minimal loss of produce \\
\hline \multirow[t]{6}{*}{ Energy } & Source of cooking fuel & $\begin{array}{l}\text { Traditional fuels are less efficient and cause } \\
\text { indoor pollution }\end{array}$ \\
\hline & Consumption of wood as fuel & $\begin{array}{l}\text { More wood being used as fuel causes } \\
\text { more pollution }\end{array}$ \\
\hline & Sources of light & Light increases working/reading hours \\
\hline & Spending on energy & $\begin{array}{l}\text { More spending on energy leads to lower } \\
\text { human effort }\end{array}$ \\
\hline & Appliances for lighting & Efficient appliances consume less energy \\
\hline & Appliances for cooking and eating & Protection from extreme environmental conditions \\
\hline \multirow[t]{3}{*}{ Employment vulnerability } & Regular earning members & Job security leads to lower vulnerability \\
\hline & Total earning members & More earning members $=$ economic empowerment \\
\hline & Average working days in a month & More working days $=$ more income \\
\hline \multirow[t]{4}{*}{ Infrastructure } & Type of house & $\begin{array}{l}\text { Concrete houses lend more security to the family } \\
\text { and agricultural produce }\end{array}$ \\
\hline & Use of toilet & Prevention of diseases \\
\hline & Access to medical care in villages & Prevention of diseases and health checks \\
\hline & Distance to multispecialty hospital & Saves lives in an emergency \\
\hline \multirow[t]{5}{*}{ Socioeconomic } & Community (Caste) & Lower social class $=$ higher vulnerability \\
\hline & Economic class & Lower economic class = higher vulnerability \\
\hline & Family size & Bigger family size creates more dependency \\
\hline & Highest education & Education helps with decision-making \\
\hline & Type of school & $\begin{array}{l}\text { Private school-educated children are } \\
\text { more up-to-date }\end{array}$ \\
\hline \multirow[t]{4}{*}{ Social security } & Member of SHGs & Get help from other members and banks \\
\hline & Participation in panchayat & Empowerment \\
\hline & Access to credit & Help in an emergency \\
\hline & Loans & Loan is a liability \\
\hline Distance to highway & Distance to highway & Provides access to all basic facilities \\
\hline \multirow[t]{5}{*}{ Water } & Source of drinking water & $\begin{array}{l}\text { Water from a contaminated source causes } \\
\text { many diseases }\end{array}$ \\
\hline & Distance to drinking water & Distance $=$ more time \\
\hline & Time spent on water collection & Time can be devoted to other uses \\
\hline & Quality of water & Prevention of water borne disease \\
\hline & Daily water use, in liters & More water use $=$ more vulnerability \\
\hline \multirow[t]{4}{*}{ Climate variability * } & Variation in maximum temperature & Maximum temperatures lead to crop damage \\
\hline & Variation in minimum temperature & Minimum temperatures lead to crop damage \\
\hline & Change in frequency of rainfall & Rainfall variation damages crops \\
\hline & Number of drought and flood events & Extreme environmental conditions \\
\hline
\end{tabular}

* Data were not available at the village level, so the authors removed the climate data from the vulnerability calculation by assuming similar environmental conditions. 


\section{Appendix B}

Table A2. PostHoc Test (LSD) of ANOVA of Different Socioeconomic Parameters with Respect to Vulnerability Score.

\begin{tabular}{|c|c|c|c|c|c|}
\hline Dependent Variable & IVs & Ivs & $\begin{array}{l}\text { Hoshangabad } \\
\text { Sig ( } p \text { Value) }\end{array}$ & $\begin{array}{c}\text { Mandla } \\
\text { Sig ( } p \text { Value) }\end{array}$ & $\begin{array}{c}\text { Total } \\
\text { Sig ( } p \text { Value })\end{array}$ \\
\hline \multirow{3}{*}{ Vulnerability } & \multirow{2}{*}{ ST } & SC & 0.023 & 0.543 & 0.007 \\
\hline & & OBC & 0.000 & 0.252 & 0.001 \\
\hline & SC & OBC & 0.015 & 0.333 & 0.882 \\
\hline \multirow{3}{*}{ Vulnerability } & \multirow{2}{*}{ AY } & BPL & 0.000 & 0.779 & 0.000 \\
\hline & & APL & 0.000 & 0.000 & 0.000 \\
\hline & BPL & APL & 0.000 & 0.001 & 0.000 \\
\hline \multirow{10}{*}{ Vulnerability } & \multirow{4}{*}{ Illiterate } & Middle & 0.009 & 0.841 & 0.029 \\
\hline & & Matric & 0.000 & 0.690 & 0.000 \\
\hline & & Intermediate & 0.000 & 0.592 & 0.024 \\
\hline & & Graduation & 0.000 & 0.374 & 0.000 \\
\hline & \multirow{3}{*}{ Middle } & Matric & 0.011 & 0.589 & 0.009 \\
\hline & & Intermediate & 0.018 & 0.487 & 0.420 \\
\hline & & Graduation & 0.000 & 0.302 & 0.000 \\
\hline & \multirow{2}{*}{ Matric } & Secondary & 0.505 & 0.938 & 0.206 \\
\hline & & Graduate & 0.001 & 0.680 & 0.000 \\
\hline & Intermediate & Graduate & 0.110 & 0.719 & 0.000 \\
\hline \multirow{3}{*}{ Vulnerability } & \multirow{2}{*}{ Labor } & Other & 0.000 & 0.006 & 0.000 \\
\hline & & Salaried & 0.000 & 0.000 & 0.000 \\
\hline & Other & Salaried & 0.817 & 0.051 & 0.006 \\
\hline
\end{tabular}

\section{Appendix C}

Table A3. Regression Results.

\begin{tabular}{cccccc}
\hline \multirow{2}{*}{ Model } & \multicolumn{2}{c}{ Unstandardized Coefficients } & Standardized Coefficients & \multirow{2}{*}{$\boldsymbol{t}$} & \multirow{2}{*}{ Sig. } \\
\cline { 2 - 5 } & $\mathbf{B}$ & Std. Error & Beta & & \\
\hline (Constant) & 37.789 & 0.821 & 0.284 & 6.002 & 0.000 \\
Education level & 1.872 & 0.302 & 0.373 & 0.000 \\
Occupation (Livelihood option) & 5.208 & 0.613 & 0.199 & 8.490 & 0.000 \\
Social class & 1.235 & 0.506 & 2.439 & 0.015 \\
Economic class & 3.491 & 0.672 & 0.231 & 5.192 & 0.000 \\
\hline
\end{tabular}

Dependent Variable: CCVI.

\section{References}

1. Hennessy, K.; Fitzharris, B.; Bates, B.C.; Harvey, N.; Howden, S.M.; Hughes, L. Climate Change Impacts, Adaptation and Vulnerability. In Contribution of Working Group II to the Fourth Assessment Report of the Intergovernmental Panel on Climate Change; Cambridge University Press: Cambridge, UK, 2007.

2. Intergovernmental Panel on Climate Change (IPCC). Fourth Assessment Report of the Intergovernmental Panel on Climate Change Glossary Climate Change, Climate Change Impacts, Adaptation and Vulnerability; Cambridge University Press: Cambridge, UK, 2007.

3. Intergovernmental Panel on Climate Change (IPCC). Climate Change 2014-Impacts, Adaptation and Vulnerability: Regional Aspects; Cambridge University Press: Cambridge, UK, 2014. 
4. Kopits, E.; Marten, A.; Wolverton, A. Incorporating 'catastrophic' climate change into policy analysis. Clim. Policy 2014, 14, 637-664. [CrossRef]

5. Hitz, S.; Smith, J. Estimating global impacts from climate change. Glob. Environ. Chang. 2004, 14, $201-218$. [CrossRef]

6. Parmesan, C.; Yohe, G. Agloballycoherentfingerprintofclimatechangeimpactsacrossnaturalsystems. Nature 2003, 421, 37-42. [CrossRef] [PubMed]

7. Braatz, S. Building resilience for adaptation to climate change through sustainable forest management. In Building Resilience for Adaptation to Climate Change in the Agriculture Sector; Meybeck, A., Lankoski, J., Redfern, S., Azzu, N., Gitz, V., Eds.; FAO: Rome, Italy, 2012; pp. 117-127.

8. Singh, K.D.; Sinha, B.; Mukherji, S.D. Exploring Options for Joint Forest Management in India; Food and Agriculture Organization of the United Nations: Rome, Italy, 2005.

9. FAO; CIFOR. FAO Framework Methodology for Climate Change Vulnerability Assessments of Forests and Forest Dependent People; FAO: Rome, Italy, 2019.

10. Smit, B.; Wandel, J. Adaptation, adaptive capacity and vulnerability. Glob. Environ. Chang. 2006, 16, $282-292$. [CrossRef]

11. Nelson, D.R.; Adger, W.N.; Brown, K. Adaptation to environmental change: Contributions of a resilience framework. Annu. Rev. Environ. Resour. 2007, 32, 395-419. [CrossRef]

12. Environmental Planning and Coordination Organization (EPCO). State Knowledge Management Center for Climate Change; The Government of Madhya Pradesh: Bhopal, India. Available online: http://www.epco.in/ pdfs/ClimateChange/Vulnerability_Assessment_of_MP.pdf (accessed on 24 December 2014).

13. Jha, S.K.; Mishra, S.; Sinha, B.; Alatalo, J.M.; Pandey, R. Rural development program in tribal region: A protocol for adaptation and addressing climate change vulnerability. J. Rural Stud. 2017, 51, 151-157. [CrossRef]

14. Gallopín, G.C. Linkages between vulnerability, resilience, and adaptive capacity. Glob. Environ. Chang. 2006, 16, 293-303. [CrossRef]

15. Adger, W.N. Social Vulnerability to Climate Change and Extremes in Coastal Vietnam. World Dev. 1999, 27, 249-269. [CrossRef]

16. Adger, W.N. Vulnerability. Glob. Environ. Chang. 2006, 16, 268-281. [CrossRef]

17. Census ofI ndia. House listing and Housing Census Schedule. In Ministry of Home Affairs; Office of Registrar General and Census Commissioner, Government of India: New Delhi, India, 2011.

18. Kothawale, D.R.; Munot, A.A.; Kumar, K.K. SurfaceairtemperaturevariabilityoverIndiaduring1901-2007, and its association with ENSO. Clim. Res. 2010, 42, 89-104. [CrossRef]

19. Ministry of Environment. Indian Network for Climate Change Assessment (INCCA) \& India. In Climate Change and India: A 4 X 4 Assessment, a Sectoral and Regional Analysis for 2030s; Ministry of Environment \& Forests, Government of India: New Delhi, India, 2010; Volume 2.

20. Kishwan, J.; Ravindranath Dutt, C.B.S.; Sukumar, P.R. Planning Commission: Sub-Group on Climate Change for 12th Five Year Plan on Mitigation and Adaptation in the Forestry Sector; Indian Forest Congress: Deheradun, India, 2011.

21. Ministry of Tribal Affair "MoTA". Government of India, Forest Right Act. 2013. Available online: http: //tribal.nic.in/WriteReadData/CMS/Documents/201311130217562366178LettertoCSofallState.pdf (accessed on 15 October 2014).

22. Bahuguna, V.K. Forests in the economy of the rural poor: An estimation of the dependency level. Ambio A J. Hum. Environ. 2000, 29, 126-130. [CrossRef]

23. Chaturvedi, R.K.; Gopalakrishnan, R.; Jayaraman, M.; Bala, G.; Joshi, N.V.; Sukumar, R.; Ravindranath, N.H. Impact of climate change on Indian forests: A dynamic vegetation modeling approach. Mitig. Adapt. Strategy Glob. Chang. 2011, 16, 119-142. [CrossRef]

24. Sinha, B.; Vasisht, A.; Omprakash, M.D.; Ghosh, M.; Devi, R.M.; Patasaraiya, M.K.; Yadava, R.N.; Kinhal, G.A.; Bisaria, J. Opportunities of Renewable Energy Interventions in Forest Fringe Villages of Madhya Pradesh; New Connaught Place Dehradun: Connaught Place, India, 2018.

25. Mishra, V.; Shah, R.; Garg, A. Climate change in Madhya Pradesh: Indicators, Impacts and Adaptation; Indian Institute of Management: Ahamdabad, India, 2016. 
26. Devi, R.M.; Sinha, B.; Bisaria, J.; Saran, S. Multitemporal analysis of forest cover change using remote sensing and gis of kanha tiger reserve, central India. Int. Arch. Photogramm. Remote Sens. Spat. Inf. Sci. 2018, in press. [CrossRef]

27. Patasaraiya, M.K.; Sinha, B.; Bisaria, J.; Saran, S.; Jaiswal, R.K. Assessig of climate change on teak and sal landscape using modis time series data. Int. Arch. Photogramm. Remote Sens. Spat. Inf. Sci. 2018, in press. [CrossRef]

28. Gandhi, A. India Human Development Report 2011: Towards Social Inclusion; Oxford University Press: Oxford, UK, 2011.

29. Mehta, A.K.; Shah, A. Chronic poverty in India: Incidence, causes and policies. World Dev. 2003, 31, 491-511. [CrossRef]

30. Mishra, A.K.; Singh, V.P. A review of drought concepts. J. Hydrol. 2010, 391, 202-216. [CrossRef]

31. Yadava, R.N.; Sinha, B. Scoring Sustainability Reports Using GRI2011 Guidelines for Assessing Environmental, Economic, and Social Dimensions of Leading Public and Private Indian Companies. J. Bus. Ethics 2016, 138, 549-558. [CrossRef]

32. Holling, C.S. Foreword: The backloopto sustainability. In Navigating Social-Ecological Systems: Building Resilience for Complexity and Change; Cambridge University Press: Cambridge, UK, 2003; Volume XV-XXI.

33. Shukla, R.; Chakraborty, A.; Joshi, P.K. Vulnerability of agro-ecological zones in India Under the earth system Climate Model Scenarios. Mitig. Adapt. Strateg. Glob. Chang. 2017, 22, 399-425. [CrossRef]

34. UNDP (United Nation Development Programme). Human Development Report, United Nations Development Program. 2006. Available online: http://hdr.undp.org/hdr2006/statistics/ (accessed on 24 December 2014).

35. Hahn, M.B.; Riederer, A.M.; Foster, S.O. The Livelihood Vulnerability Index: A pragmatic approach to assessing risks from climate variability and change-A case study in Mozambique. Glob. Environ. Chang. 2009, 19, 74-88. [CrossRef]

36. Esteves, T.; Ravindranath, D.; Beddamatta, S.; Raju, K.V.; Sharma, J.; Bala, G.; Murthy, I.K. Multi-scale vulnerability assessment for adaptation planning. Curr. Sci. 2016, 110, 1225-1239.

37. Mohanty, A.K.; Kumar, G.A.K.; Singh, B.B.; Meera, S.N. Developing multidimensional scale for effective measurement of rural leadership. Indian Res. J. Ext. Educ. 2016, 9, 57-63.

38. Ranganathan, C.R.; Singh, N.P.; Bantilan, M.C.S.; Padmaja, R.; Rupsha, B. Quantitative assessment of Vulnerability to Climate Change: Computation of Vulnerability indices 2009. Available online: http://danida.vnu.edu.vn/cpis/files/Papers_on_CC/Vulnerability/Quantitative\%20assessment\%20of\% 20Vulnerability\%20to\%20Climate\%20Change.pdf (accessed on 7 February 2020).

39. Freudenberg, M. Composite Indicators of Country Performance; OECD Publishing: Paris, France, 2009.

40. Pandey, R.; Jha, S. Climatevulnerabilityindex-measureofclimatechangevulnerabilitytocommunities: A case of rural Lower Himalaya, India. Mitig. Adapt. Strateg. Glob. Chang. 2012, 17, 487-506. [CrossRef]

41. Ganesan, K.; Vishnu, R. Energy Access in India-Today, and Tomorrow. CEEW (Councilon Energy, Environment \& Water) Working paper 2014, 1. Available online: https://www.oecdilibrary.org/docserver/405566708255.pdf?expires=1581072099\&id=id\&accname=guest\&checksum= E0FAAC3C7FA00E4F16E1AC01CC50D17C (accessed on 7 February 2020).

42. Goli, S.; Maurya, N.K.; Sharma, M.K. Continuing caste inequalities in rural Uttar Pradesh. Int. J. Sociol. Soc. Policy 2015, 35, 252-272. [CrossRef]

43. Swaminathan, M. The new poverty line: A methodology deeply flawed. Indian J. Hum. Dev. 2010, 4, 121-125. [CrossRef]

44. Yadava, R.N.; Sinha, B. Strengthening Adaptive Capacity to Climate Change Vulnerability: Opportunities through Corporate Social Responsibility. In CSR Corporate Social Responsibility: The New Paradigm; Bloomsbury Publication: New Delhi, India, 2017; pp. 102-121. ISBN 9789385936272.

45. Ding, W.; Jimoh, S.; Hou, Y.; Hou, X.; Zhang, W. Influence of Livelihood Capitals on Livelihood Strategies of Herdsmen in Inner Mongolia, China. Sustainability 2018, 10, 3325. [CrossRef]

46. Antwi, E.K.; Boakye-Danquah, J.; Owusu, A.B.; Loh, S.K.; Mensah, R.; Boafo, Y.A.; Apronti, P.T. Community vulnerability assessment index for flood prone savannah agro-ecological zone: A case study of Wa West District, Ghana. Weather Clim. Extrem. 2015, 10, 56-69. [CrossRef] 
47. Ishtiaque, A.; Eakin, H.; Chhetri, N.; Myint, S.W.; Dewan, A.; Kamruzzaman, M. Examination of coastal vulnerability framings at multiple levels of governance using spatial MCDA approach. Ocean Coast. Manag. 2019, 171, 66-79. [CrossRef]

48. Esteves, T.; Rao, K.V.; Sinha, B.; Roy, S.S.; Rao, B.; Jha, S.; Murthy, I.K. Agricultural and livelihood vulnerability reduction through the MGNREGA. Econ. Political Wkly. 2013, 48, 94-103.

49. Pandey, R.; Maithani, N.; Aretano, R.; Zurlini, G.; Archie, K.M.; Gupta, A.K.; Pandey, V.P. Empirical assessment of adaptation to climate change impacts of mountain households: Development and application of an Adaptation Capability Index. J. Mt. Sci. 2016, 13, 1503-1514. [CrossRef]

50. Minimol, M.C.; Makesh, K.G. Empowering rural women in Kerala: A study on the role of Self Help Groups (SHGs). Int. J. Sociol. Anthropol. 2012, 4, 270.

51. Kumar, A. Justice and politics in energy access for education, livelihoods and health: How socio-cultural processes mediate the winners and losers. Energy Res. Soc. Sci. 2018, 40, 3-13. [CrossRef]

(C) 2020 by the authors. Licensee MDPI, Basel, Switzerland. This article is an open access article distributed under the terms and conditions of the Creative Commons Attribution (CC BY) license (http://creativecommons.org/licenses/by/4.0/). 